\title{
The Urgency of Legal Protection to the Trademarks in the Global Era
}

\author{
Anis Mashdurohatun \\ Faculty of Law Unissula \\ anism@unissula.ac.id \\ Gunarto \\ Faculty of Law Unissula \\ gunarto@unissula.ac.id \\ Lathifah Hanim \\ Faculty of Law Unissula \\ l.hanim@unissula.ac.id
}

\begin{abstract}
Globalization is nothing but capitalism in its most recent form. Strong and rich countries practically control the world economy and smaller countries are increasingly powerless because they are unable to compete through Intellectual Property Protection including trademarks. The purpose of this research is to examine and to analyze the role of the State in providing legal protection Against trademarks, and factors that influence and formulate their legal protection policies. The approach method in this research is empirical juridical. The data used were primary and secondary data. The results of the research were analyzed analytical descriptively. The results of the study found that the role of the State in providing legal protection for trademarks of business people was not optimal, this was due to several factors including the low understanding of the importance of trademark intellectual property rights protection for businesses and society as consumers. Government policies globally through the Asean Economic Community Blueprint, which contains four main pillars, including the economic competitiveness of Intellectual Property Rights integrated with the global economy.
\end{abstract}

Keywords: Legal Protection, Global Area, Trademarks.

\section{A. INTRODUCTION}

The brand serves as a differentiator and guarantees the quality of products and/or services to types based on the class of goods and/or services. ${ }^{1}$

Basically, Brand is a right that arises as a result of human intellectual ability in various fields that produce a

1 Law No 20 year 2016 on Trademark and Geographical Indication process or product that is beneficial to humanity globally. 2

Registered Trademarks/Services, in formal legality under the Brand Law and Geographical Indications, get legal protection both civil and criminal. In the development of global economic trade registered trademarks
2 Budi Santoso, 2009, Pengantar HKI Dan Audit HKI Untuk Perusahaan, Penerbit PustakaMagister, Semarang, page.4.

THE URGENCY OF LEGAL PROTECTION TO THE TRADEMARKS IN THE GLOBAL ERA Anis Mashdurohatun, Gunarto, Latifah Hanim 
are one of the four main pillars of the AEC (Asean Economic Community) Blueprint to realize the economic competitiveness of integrated IPR (intellectual property right) in the global economy. 3

"Globalization is a term that has a relationship with increasing linkages and dependencies between nations and between people around the world through trade, investment, travel, popular culture, and other forms of interaction so that the boundaries of a country become biased. Globalization has many characteristics in common with internationalization so that these two terms are often exchanged. Some parties often use the term globalization which is associated with the reduced role of the state or national borders. On the other hand, there are those who see globalization as a project carried out by superpowers, so that people can have negative views or be suspicious of it. From this point of view, globalization is nothing but capitalism in its most recent form. Strong and rich countries will practically control the world economy and smaller countries become more powerless because they cannot compete". 4

The main objective of the IPR system is to ensure that the creative process continues by providing adequate legal protection and providing sanctions against those who use the creative process without permission. In subsequent developments, IPRs became an economic commodity that was very promising, especially for a number of countries that made IPR producers (developed countries). This reasoning is underlying the inclusion of IPR into the international trading system. 5

On the other hand, it also encourages people to always be creative and innovate in order to improve the economic development of the community. It is done to realize the competitiveness of MSMEs globally, which will automatically support the realization of the nation's ideals as mandated by the Constitution of the Republic of Indonesia in the opening of the Constitution Republic of Indonesia in 1945 , namely improving the welfare of the people.

4 Anis Mashdurohatun, 2018, Hukum Hak Cipta Atas $B u k u$,Rajagrafindo,Jakarta, page.9

5 Anis Mashdurohatun,2016, Mengembangkan fungsi sosial hak cipta atas buku, UNS Press, Surakarta, page. 120 . 
Trademarks are brands used on goods traded by a person or several people together or a legal entity to distinguish them from other similar items. 6

Mainwaring et al. (2004) applying the zero-inflated Poisson model to explain the number of trademarks in 3500 companies located in three regions of England and Ireland. The authors found that the number of trademarks increased with the size of the company. Specifications do not directly estimate the impact of company size on the intensity of trademark use. However, marginal effects indicated that large companies can use trademarks more intensively. Allegrezza and Guard-Rauchs in their study in (1999) as cited by Schautschick and Greenhalgh (2013) attempted to explain the mechanism related to company decisions to store trademarks. They found a significant positive relationship between trademarking and $R$ \& $D$ intensity, as measured by the frequency of $R \& D$ activity in the company. Given that R $\& D$ is often used to project innovative activities, this seems to indicate the relationship between innovation and

8 Muhamad Djumhana, 2014, Hak Milik Intelektual, Sejarah, Teori, dan Praktiknya Di Indonesia, PT. Citra Aditya Bakti, Bandung, P. 169 trademarks. However, given the small variety of industries in which companies conduct formal $R \& D$, especially manufacturing, this research does not mean definitive. The results provide evidence that larger companies are more likely to register trademarks.

Ali Reza Mehrazeen's ${ }^{7}$ research results showed that assessing intangible assets is an important problem in modern economics; one of the most important is a trademark. In trademarks competitive, businesses can protect and create profits for the company. In an increasingly complex and increasingly fast-growing market today, appropriate trademarks affect the company's performance and are considered as fundamental economic assets for the organization. Assessing intangible assets and determining their relationship with performance indicators has two main benefits, first it can be useful for various stakeholders such as shareholders, creditors and employees in assessing company performance and both of them can draw attention to standard tuners on the importance of

7 Ali Reza Mehrazeen, Omid Froutan \& Navid Attaran ,Establishing the Relationship between Trademark Valuation and Firm Performance: Evidence from Iran, International Journal of Economics and Finance, Vol. 4, No. 6; June 2012, P. 181. 
recognizing and measuring trademarks and other intangible assets in financial statements.

Based on the above issues, it is interesting to examine in depth the role of the State in providing legal protection to trademarks, and the factors that influence and formulate trademark legal protection policies in the future.

\section{B. RESEARCH METHODS}

The method of approach in this study is juridical empirical, this research approach was chosen to see how far the effectiveness of law in society with the factors that influence it. According to Briand Z Tamanaha, between law and society has a frame called "the law society framework" which has certain relationship characteristics. The relationship is indicated by two basic components. The first component consists of two main themes, namely the idea that law is a mirror of the society and the idea is a legal function to maintain "social order". The second component consists of three elements, namely: custom/consent; morality/reason; and positive law custom/consent and morality/reasons can be understood in
Donald Blak's thinking as culture. ${ }^{8}$ The data used were primary and secondary data. The results of the research data were analyzed analytical descriptively.

\section{RESEARCH RESULTS AND DISCUSSION}

\section{C.1. The Role of the State in Providing Legal Protection to Trademarks}

Friedman $^{9}$ stressed that the duty of the state as a "regulator" is to regulate all aspects of the lives of citizens including in the economic field. Friedman explained in detail that

8 Djauhari,2008 Politik Hukum Negara

kesejahteraan, Unissula Press,Semarang, P. 99.

9 W. Friedman, Law in a Changing Society, Stevens, London, 1959, page. 495. Furthermore according to Spicker, welfare state can be defined as a social welfare system that gives a greater role to the state or government to allocate a portion of public funds to ensure the fulfillment of the basic needs of its citizens. This concept, takes the country to provide protection to its citizens, especially in the weak group. The state is required to expand its responsibilities to the socio-economic problems faced by its people. This development provides a basis for legislation for the state to intervene in a variety of social and economic issues to ensure mutual welfare in society. Furthermore, the characteristics of the Welfare State is that the government is obliged not only to take care of defense and security but also other lives, namely education, youth, sports, economy, environment, arts, culture and so on. Mohammad Hatta named the welfare state as a 'board' state in European history. According to Utrecht, a country like this was born at the end of the 19th century and the beginning of the 20th century. see Muhammad Alim, Asas-Asas Negara Hukum Modern Dalam Islam: Kajian Komprehensif Islam dan Ketatanegaraan, LKiS, Yogyakarta, 2010, page. 234-235.lihat juga dalam Anis Mashdurohatun, 2016, Mengembangkan Fungsi Sosial Hak Cipta Atas Buku, UNS Press, Surakarta, P.1 
there are five types of tasks from a welfare state, namely as a protector of citizens, executors or bodies that are obliged to carry out community needs, as economic supervisors and as judges or mediators. The concept of the welfare state/Indonesian welfare state is implied in the 1945 Constitution of the Republic of Indonesia 1945.

The implementation of economic democracy carried out through trade activities is a major driver in national economic development that can provide support in increasing production and equalizing income and strengthening the competitiveness of domestic products. The role of trade is very important in enhancing economic development, but in its development it has not met the need to face the challenges of national development so that economic political alignments are needed that provide more opportunities, support and development of the people's economy which includes cooperatives as well as micro, small and medium enterprises as the main pillars national economic development. Trade requires harmonization of provisions in the field of trade within the framework of national economic unity in order to address the development of the trade situation in the present and future globalization era. ${ }^{10}$

The role of the State in providing legal protection for trademarks of business actors based on constitutional mandate through the Government's policy in developing the community's economy has been carried out continuously, by compiling the 2005-2025 National Long-Term Development Plan. It is the mandate of Article 33 of the Republic of Indonesia State Constitution 1945. Government legal policy in increasing investment competitiveness is in accordance with Indonesia's Vision and Mission 2005-2025.

Through the establishment of legislation, namely Law Number 20 year 2016 concerning Brands and Geographical Indications, Law Number 42 year 1999 concerning Fiduciary Guarantees, Law Number 7 year 2014 concerning Trade, Government Regulation Number 24 year 1993 concerning List of Goods Classes or Services, Government Regulation of the Republic of Indonesia Number 45 year 2016 concerning Second Amendment to Government

10 Law No 7 year 2014 on Trading. 
Regulation Number 45 year 2014 concerning Types and Tariffs of Types of Non-Tax State Revenues Applicable to the Ministry of Law and Human Rights and Government Regulation Number 21 year 2015 concerning Procedures Registration of Fiduciary Guarantees and Costs for Making Deed of Fiduciary Guarantee.

In addition, the AEC Blueprint is a guideline for ASEAN Member States to reach the $2015 \mathrm{AEC}$, where each country is obliged to implement commitments in the blueprint. The AEC Blueprint contains four main pillars, including the economic competitiveness of IPRs that are integrated with the global economy.

Brand registration began in 1990-1992, only 7 registrants were registered, from 1993-1994, recorded 89 registrants. In 2018, January to August the brand registration through WIPO Brand Global amounted to 40,556 thousand, in 2017 amounted to 68,580 thousand, in 2016 amounted to 66,173 thousand, in 2015 amounted to 61,910 thousand, in 2014 amounted to 61,587 and in 2013 amounted to 67,788 thousand. So that in the past 6 years, there were 366,604 (three hundred sixty six thousand and six hundred four) registrations. The development of Indonesian trademark registration from year to year can be clearly seen in the table below.

\section{Table.1.}

Indonesian Trademark Registration ${ }^{11}$

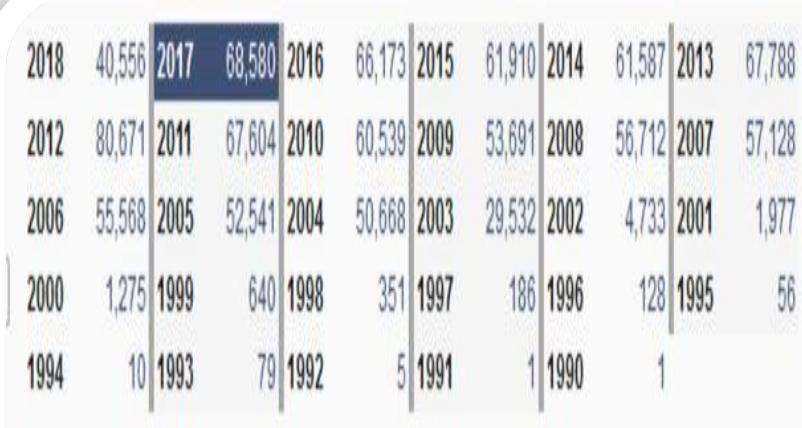

Based on national trademark registration data, the registration has experienced a very significant development, but not comparable with the data of SMEs (Small Medium Enterprises) that live and develop in Indonesia, because it is still a trademark that has not been registered through the Directorate General of IPR. The role of the state as a regulator is realized by the products of laws and regulations that have been made, but the role of the state in providing trademark

11 Source: Global Brand Database, Ministry of Law and Human Right, Dirdjen KI 2018 
protection for business actors has not been optimal because there are many counterfeit brands and brands that basically lead to brand closure by the Court.

\section{C.2. Factors Affecting in Providing} Legal Protection to Trademarks

Law as a system, namely the substance of the law, the legal structure and the culture of law, often cannot be entirely followed by changes in society, especially those which have occurred since the phenomenal reform period in Indonesia. Lawrence M. Friedman further stated that the legal system includes three components, namely: Structure, Substance and Culture ${ }^{12}$. Meanwhile, according to Robert $B$. Seidmen and William J. Cambliss that the successful implementation of a law is very much dependent on many factors, in general the workings of law in society will be determined by several main factors, namely: concerning the making of legislation (normative juridical), the parties and the role of the government and concerning economic considerations

12 Lawrence M.Friedman,2009,System Hukum Dalam Perspektif Ilmu Sosial,The Legal System:A social Science Perspektive, Nusa Media ,Bandung, P.16 and business culture (sociological juridical nature). ${ }^{13}$

The legal substance determines whether or not a law can be implemented. Besides that, the substance of the law includes living law, not only the rules in the law (law books). Furthermore, the law that lives in society can be used as a reference in establishing a just law. ${ }^{14}$

Satjipto Rahardjo, stated that "The law is not in the air or in a vacuum, but in society". Furthermore, he said, "Law in relation to the sense of public justice, the law is considered as a channel for all the difficulties faced by society. ${ }^{15}$

Norway, provides some clues about the possibility of SMEs to use trademarks. Gathering several thousand applicants, including microenterprises and SMEs, (Iversen, 2003) underlines that less than $30 \%$ of the smallest companies identified are involved in two or more trademark applications while the percentage increases to $90 \%$ for large companies.

13 Suteki, 2008, Rekonstruksi Politik Hukum tentang Hak Menguasai Negara Atas Sumber Daya Air Berbasis Nilai Keadilan Sosial (Studi Terhadap Privatisasi Pengelolaan Sumber Daya Air), Disertasi pada Program Doktor Ilmu Hukum Universitas Diponegoro, Semarang, P.110

14 Lawrence M Friedman, Op.Cit. page. 34

15 Satjipto Rahardjo, 2004, Demokrasi Butuh Dukungan Hukum Progresif, an article in daily Kompas 22 June 2004, Jakarta, P. 11. 
This rough analysis shows a positive correlation between the size and number of trademark applications. (Mamede \& Fernandes, 2011) conducted research in Portugal, their regression results largely confirmed the idea that the size and age of companies is a relevant determinant of the use of trademarks. In particular, new companies express a higher tendency to mark trade, while trademark use is more likely among larger companies than smaller ones. Regression results also showed that geographical proximity plays an important role in explaining the use of trademarks by companies (even after controlling for a higher tendency of companies located in the metropolitan center to use trademarks). In fact, regional effects showed more importance than industrial effects. However, according to the authors the company's special features are the most important determinants of the use of trademarks. ${ }^{16}$

Considerations The case, as laid out in the summary above, provides ample evidence to substantiate the following considerations: First, Lack of cancellation procedures for

16 Mirësi Çela,The importance of Trademarks and a review of empirical studies, European Journal of Sustainable Development (2015), 4, 3, 125-134 ISSN: 2239-5938, P. 132. trademarks registered in "Bad Faith" to Mexican Companies Tiendas Oficiales acted in bad faith by registering a confusingly similar trademark to those owned by its licensor, Grupo Anderson's. Tiendas Oficiales then enforced its registrations 1034 Vol. 99 TMR against other licensees of Grupo Anderson's in efforts to block legitimate competition. Under the current Mexican Industrial Property Law, Grupo Anderson's, as a Mexican company, is precluded from canceling Tiendas Oficiales' confusingly similar trademark registrations, which were obtained in bad faith. Pursuant to Article 151, Section $V$ of the Mexican Industrial Property Law, a trademark registration may only be declared null and void on the basis that the mark was registered in bad faith in circumstances involving foreign trademark owners. As such, the owner of a Mexican trademark registration has no recourse against an agent, representative, licensee or distributor who applies to register an identical or confusingly similar mark in its own name without consent. Second, "Equal Protection Argument"Mexican Legislation does not provide for Equal Protection as Stipulated in Mexico's Constitution 
Article 151 , Section $V$ of the Mexican Industrial Property Law is unconstitutional in that the Mexican Constitution provides that the civil rights granted therein apply to all individuals. As stated above, however, the law does not permit a Mexican company to seek cancellation of trademarks registered in "bad faith." It therefore contravenes the constitution. Third, Mexico's compliance with International Agreements Article 151, Section $V$ is inconsistent with the international treaties to which Mexico has subscribed, i.e., TRIPS and NAFTA. In fulfillment of these treaty obligations, the Mexican Supreme Court has issued a ruling that all international treaties approved by the Senate and by the President are categorized above federal laws (i.e., Mexican Industrial Property Law), and are considered in the same rank as the Constitution. Under NAFTA and TRIPS, Mexico is obligated to implement certain standards and procedures for the protection of intellectual property. Part IV (Article 62) of TRIPS, which concerns the acquisition and maintenance of intellectual property rights and related inter partes procedures, authorizes Members to subject the acquisition and maintenance of intellectual property rights to the compliance by the applicant or right holder with "reasonable" procedures and formalities that are fair and equitable. Furthermore, Article 1708 of NAFTA requires each party to provide a system for the registration of trademarks which shall include a reasonable opportunity for interested persons to cancel the registration of a trademark. Vol. 99 TMR 1035 In addition, Article 3 of TRIPS and Chapter 17 of NAFTA each provide for the principle of national treatment. Specifically, Article 1703(1) of NAFTA states that each party shall accord to nationals of the other parties to the NAFTA treatment no less favorable than that it accords to its own nationals with regard to the protection and enforcement of all intellectual property rights. Under an interpretation a contrario sensu of such provision, the Mexican Industrial Property Law does not provide its nationals the same level of treatment accorded to those of other NAFTA countries. Accordingly, with regards to cancellation of trademark registrations obtained in bad faith, there is a discrepancy between the provisions of 
the Mexican Industrial Property Law and those contained in the governing international treaties. The Supreme Court's position is that where such a discrepancy exists between a federal law and an international treaty, the latter must prevail. As such, the Mexican Industrial Property Law ought to be interpreted so that it does not limit the cancellation of trademark registrations obtained in bad faith to circumstances involving foreign trademark owners only. ${ }^{17}$

Convoluted bureaucracy and high costs and assistance in registering trademarks have not been maximized.

Community Legal Culture is closely related to community legal awareness. The higher the legal awareness of the community should be able to create a good legal culture and can change the mindset of the public regarding the law so far. Unfortunately, the Indonesian people's legal culture wants to make a big profit, but does not want to work hard, and does not want to think. They want it to make a big profit by imitating or hijacking other famous brands. Almost all Indonesian people,

17 The TradeMark Reporter, The Law Journal of the International Trademark Association, Vol. 99 JulyAugust, 2009 No. 4 , P. 1033-1035. if possible they do the similar things. Apart from the aspect of community legal culture, there are also several other factors. Other factors that hinder protection include the low understanding of the importance of trademark intellectual property rights protection for businesses through trademark registration, the convoluted view of the bureaucracy, even though registration through E-IPR and the high cost of fees for SMEs is already valid. free brand registration policy, as well as mentoring trademark registrations that have not been maximized because they are comprehensively socialized.

\section{C.3. Future Legal Trademark Protection Policies}

The function of a trademark, commonly called a sign, a business brand, a brand of goods, a brand, and a trademark, initially distinguishes various sources of products or service providers, but trademarks also have other connotations. Famous trademarks, also known as famous brands, are trademarks with popularity and great reputation in certain areas. Their functions go far beyond just to distinguish product sources or service providers; they also 
represent rich connotations and comprehensive competitiveness. Trademarks are a type of intellectual property rights that are protected by law and well-known trademarks are intellectual property rights that are more valuable, and thus more vulnerable to violations. Therefore, well-known trademarks require broader and stronger protection by law. ${ }^{18}$

Intangible assets such as trademarks are considered as one of the fundamental assets of organizations in today's competitive business environment and it is anticipated that they influence the company's performance in various ways. Assessing trademarks and building relationships with performance indicators can be considered as desired measures for stakeholders, meaning that while standard makers can benefit from this while drawing their attention to important issues such as recognizing and measuring tangible financial statements. According to the findings in this study, there is a significant relationship between earnings and

18 An Qinghu, WELL-KNOWN MARKS \& CHINA'S SYSTEM OF WELL-KNOWN MARK PROTECTION, The International Trademark Association, Vol. 95 May-June, 2005 No. 3, P. 706707. trademark value, which means companies with higher trademark value are people with higher profits.

The results show the same relationship with three other performance indicators. This finding shows the importance of intangible assets that are usually not reported on the balance sheet, so that the expected reporting of trademark values on the balance sheet facilitates the decision making process by investors and leads to an increase in the company's performance appraisal, as illustrated in the table below:

\section{Table.2.}

Improvement of company performance assessment $^{19}$

\begin{tabular}{cccc}
\multicolumn{4}{l}{ Table 1. The role of trademarks in value creation for shareholders } \\
\hline Company Name & Brand value to a billion dollars in 2001 & $\begin{array}{c}\text { Value than the market value of } \\
\text { trademanks }\end{array}$ & $\begin{array}{c}\text { Brand value to a billion dollars in } \\
\text { Coca-Cola }\end{array}$ \\
Microsott & 69 & $51 \%$ & 2002 \\
IBM & 95.1 & $21 \%$ & 69.6 \\
GE & 52.8 & $39 \%$ & 64.1 \\
Intel & 42.4 & $14 \%$ & 51.2 \\
Nokia & 32.7 & $22 \%$ & 41.3 \\
Disney & 35 & $51 \%$ & 30.9 \\
Mclonald's & 32.6 & $68 \%$ & 30 \\
Martborough & 25.3 & $71 \%$ & 29.3 \\
Mercedes-Benz & 22.1 & $20 \%$ & 26.4 \\
\hline
\end{tabular}

Marketing

content communication writing skills, strategies (2) social application skills in creating social impact for customers
19 Ali Reza Mehrazeen etc,Ibid P. 185-186. 
(3) and social customer relationship management skills (SCRM). ${ }^{20}$

Table 1 illustrates the extent to which trademarks can affect a company's economic performance, for example $71 \%$ of Macdonald's overall value is made by its brand/or Coca Cola which owes $51 \%$ of its value to a well-recognized trademark that exempts other affiliate brands such as Fanta or Sprite. Currently the attention of pioneer companies is shifting to intangible assets, for example Ford has reduced tangible assets through investment and acquired major intangible assets. The company has spent more than 12 billion dollars to buy Volvo, Jaguar and Land Rover (Lindemann, 2004). Research conducted by BBDO consultants (Kotler \& Pfoertsch, 2006) in 2006 investigated the impact of brands on company performance, examined 23 of the 30 companies listed on DAX, those with strong and well-known brands able to overcome the stagnation that occurred after

20 Syahmardi Yacob, Ade Octavia, Mayrina, Andri, Do Really Social Commerce Creating For Competitive Advantage On Small Medium Enterprises (Smes) Business Performance In Indonesia International Journal Of Business Research, Volume 18, Issue 2, P75, June 2018
9/11 faster than companies that do not have a weak trademark.

Table.3.

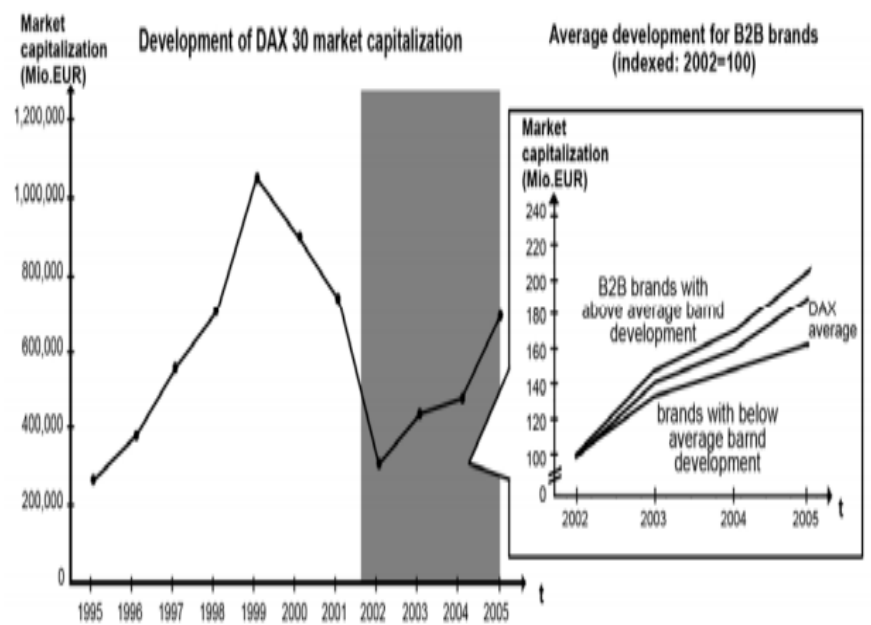

Trademark values have been demonstrated through various brand ratings and in recent studies conducted in the United States and the European Union and by the World Intellectual Property Organization (WIPO) and many other scholars interested in the field of intellectual property in general and trademarks in particular. They answered many questions, and the variables they take in consideration vary from company size, their financial performance, the use of trademarks as indicators of innovation and their combination. They show trademark positive correlation and firm size, financial performance, and in many cases serve 
as indicators to show how innovative companies are. ${ }^{21}$

\section{From a Legal Perspective}

Registering a trademark is the act of a trademark owner to legally assign their rights and obligations to the product. At present, the way to implement these rights and obligations depends entirely on the owner. In essence, intellectual property rights, industrial property rights that cover trademark ownership rights are judicial authorities. The owner himself must protect his rights. State institutions will only intervene when there is a request from the owner. Therefore, if another company violates a trademark (by falsifying, imitating), or using this trademark without the permission of its owner, the trademark owner has the right to request an infringer to stop the violation or request intervention from the competent authority. At present, in Vietnam, market supervision institutions have found many cases of large-scale counterfeiting and imitation of high-quality goods. These high quality items are trusted by consumers and have become registered trademarks. Counterfeiting and imitation occur almost openly, and the owner himself cannot control each case. This shows that the benefits of customers and companies can be guaranteed only when the Vietnamese government has found a solution to protect the rights of trademark owners. The Vietnamese government needs to support trademark owners to exercise their rights. Some recommendations will be mentioned below:

First, it is necessary to establish evaluation criteria for international trademark groups, to help Vietnamese products be accepted and consumed on international markets. Therefore, it is imperative for the Government to issue detailed documents to guide legal applications uniformly and legally.

Second, to intensify the examination, examine and coordinate activities strictly among functional officials and trademark owners, to comply with legal regulations when detecting and punishing counterfeiting, cloning. Violations of industrial property, including trademark property in Vietnam, will be subject to administrative penalties. Tighter, it can be demanded for criminal liability. According to Decree No. 97 (NĐ 97/2010 / NĐ-CP dated 
9/21/2010), regulates administrative penalties for violations of trademark ownership rights, penalties for violations of trademark rights, geographical indications, trade names and industrial designs ranging from VND 3 million to VND 5 million. The highest level of punishment does not exceed VND 5 million for manufacturing, labeling and importing products that have signs that pertain to trademark ownership. However, we have learned that money from only one (fake) bag with well-known trademarks such as Dior, Louis Vuitton and Hermes sold is enough to pay fines if detected. As for criminal responsibility, the act of manufacturing and trading counterfeit products is considered a crime (Article 156, Vietnam Criminal Code 2009), with the highest sentence being 15 years in prison, but this is only applied to counterfeiting activities which has a huge forbidden advantage or causes very serious consequences. In addition, imitation measures have not been criminalized, so that only administrative penalties are imposed. According to article 171 of the Indonesian Criminal Code, the penalties applied for violations of industrial property are fines of VND 20 million to VND 200 million; or the longest three-year prison. This punishment is too light for property violations, especially industrial property because the use of property in this field can bring great benefits.

Third, functional authorities must increase their support in enforcing intellectual property rights, including trademark protection. Authorities such as market administrators and economic police must support trademark owners when they detect violations of their rights. In addition, these authorities must be active in the process of examining the business activities of companies located in the areas they handle. Violations of trademark property, especially counterfeiting and importation of counterfeit products must be detected and punished on time so that Vietnam will not become "paradise" for poor quality goods.

Fourth is to educate and to encourage customers to use high quality products, especially those that have been verified for quality and registered trademarks. When a trademark is registered, it is always accompanied by product quality standards, which is the commitment of the manufacturer and their 
responsibility for their products. Therefore, trademark owners must clearly show signs to distinguish between their products and counterfeit ones, in turn encouraging customers to find and boycott them. Customers play an important role in protecting trademark property. ${ }^{22}$

2005-2025 National Long Term Development Plan is the mandate of Article 33 of the 1945 Constitution of the Republic of Indonesia. Intellectual property rights of trademarks can bring royalties to the creator/inventor/designer/holder of state rights and foreign exchange. The global Asean Economic Community Blueprint contains four main pillars, including the economic competitiveness of Intellectual Property Rights that are integrated with the global economy. The policy of realization of preventive and repressive means of legal protection can be through the products of legislation concerning Intellectual Property, including Law Number 20 year 2016 concerning Trademarks and Geographical Indications. This legal protection is related to the

22 Nguyen Thi Yen, Pham Thi Thanh Huong, Thai Thu Thuy, Phan Van Thanh ,Trademark Protection from Legal Perspective: Case Study on Vietnamese Enterprises, The International Journal Of Business \& Management (ISSN 2321-8916), Vol 5 Issue 8 August, 2017 page. 35 implementation of the rights and obligations of the trademark owner who has registered his trademark. With the existence of legal protection, registered brand owners can use their brands with a feeling of security, accompanied by exclusive rights that are exclusive. This means that the owner of a registered trademark is the only person who has the right to use the mark and forbids others from using and possessing.

The legal protection of trademarks globally is preventive and repressive not only from the substance and legal structure, but also the most important thing is the legal culture of the Indonesian people themselves, namely increasing the legal awareness culture. Because when a law has been passed, the community is considered to know the existence of the law. Supposedly for brand owners, they are aware of the benefits provided by the law on their Trademarks.

Thus the government policy in providing legal protection globally, mapping brands that have potential internationally, nationally and locally. Realizing a legal-aware society and understanding IPRs and facilitating free brand registration by cooperating 
with universities, then ensuring the fulfillment of the formal legality of SMEs and educating the public as customers of high-quality brand products.

\section{CONCLUSION}

\section{D.1. Summary}

The role of the State in providing legal protection for trademarks of business actors has not been optimal.

Factors of legal protection for trademarks of business actors include factors of tolerance, structure and legal culture. The factor of legal culture is more dominant in influencing the trademark legal protection, it is because of the low understanding of the importance of the legal protection of trademark intellectual property rights for business people. The bureaucratic perception of business actors is complicated and the high costs and assistance of registering trademarks that have not been maximized.

Government policy in developing a sustainable community economy, through the 2005-2025 National Long Term Development Plan as the mandate of Article 33 of the 1945 Constitution of the Republic of Indonesia. Intellectual property rights of trademarks can bring royalties to the creator/inventor/designer/holder state rights and foreign exchange. The global Asean Economic Community Blueprint contains four main pillars, including the economic competitiveness of Intellectual Property Rights that are integrated with the global economy. The policy of realization of preventive and repressive means of legal protection can be through the legislation product, but the more dominant is the increase of IPR legal awareness of MSMEs and the public. 


\section{BIBLIOGRAFHY}

\section{Books}

Ali Reza Mehrazeen , Omid Froutan \& Navid Attaran ,Establishing the Relationship between Trademark Valuation and Firm Performance: Evidence from Iran, International Journal of Economics and Finance, Vol. 4, No. 6; June 2012.

An Qinghu, WELL-KNOWN MARKS \& CHINA'S SYSTEM OF WELL-KNOWN MARK PROTECTION, The International Trademark Association, Vol. 95 May-June, 2005 No. 3, page 706-707.

Anis Mashdurohatun, 2016, Mengembangkan fungsi sosial hak cipta atas buku, UNS Press, Surakarta.

Anis Mashdurohatun, 2018, Hukum Hak Cipta Atas Buku,Rajagrafindo,Jakarta.

Blueprint AEC

Budi Santoso, 2009, Pengantar HKI Dan Audit HKI Untuk Perusahaan, Penerbit PustakaMagister, Semarang

Djauhari,2008 Politik Hukum Negara kesejahteraan,Unissula Press,Semarang.

Lawrence M.Friedman,2009,System Hukum Dalam Perspektif Ilmu Sosial,The Legal System:A social Science Perspektive, Nusa Media ,Bandung.

Mirësi Çela,The importance of Trademarks and a review of empirical studies, European Journal of Sustainable Development (2015), 4, 3, 125-134 ISSN: 2239-5938.

Muhamad Djumhana, 2014, Hak Milik Intelektual, Sejarah, Teori, dan Praktiknya Di Indonesia, PT. Citra Aditya Bakti, Bandung.

Nguyen Thi Yen, Pham Thi Thanh Huong, Thai Thu Thuy, Phan Van Thanh ,Trademark Protection from Legal Perspective: Case Study on Vietnamese Enterprises, The International Journal Of Business \& Management (ISSN 2321-8916), Vol 5 Issue 8 August, 2017.

Satjipto Rahardjo, 2004, Demokrasi Butuh Dukungan Hukum Progresif, Artikel pada Harian Kompas 22 Juni 2004, Jakarta.

Suteki, 2008, Rekonstruksi Politik Hukum tentang Hak Menguasai Negara Atas Sumber Daya Air Berbasis Nilai Keadilan Sosial (Studi Terhadap Privatisasi Pengelolaan Sumber Daya Air), Disertasi pada Program Doktor Ilmu Hukum Universitas Diponegoro, Semarang.

Syahmardi Yacob, Ade Octavia, Mayrina, Andri, Do Really Social Commerce Creating For Competitive Advantage On Small Medium Enterprises (Smes) Business Performance 
In Indonesia International Journal Of Business Research, Volume 18, Issue 2, June 2018

The TradeMark Reporter, The Law Journal of the International Trademark Association, Vol. 99 July-August, 2009 No. 4.

\section{Regulations}

Law No 20 year 2016 on Trademark and Geographical Indication

Law No 7 year 2014 on Trading. 